Regala, P.S. Destinos ecoturisticos(?) e a necessidade de um planejamento: "caso" Pedra da Boca. Anais do VIII Congresso Nacional de Ecoturismo e do IV Encontro Interdisciplinar de Ecoturismo em Unidades de Conservação. Revista Brasileira de Ecoturismo, São Paulo, v.4, n.4, 2011, p. 535.

\title{
DESTINOS ECOTURISTICOS(?) E A NECESSIDADE DE UM PLANEJAMENTO: "CASO" PEDRA DA BOCA
}

\author{
Paloma de Sousa Regala* \\ *Universidade Federal da Paraíba \\ E-mail: paloma.tur@hotmail.com
}

O Ecoturismo cresceu muito nos últimos anos, segundo dizem livros, revistas, jornais, orgãos governamentais e a academia, isso devido à maior preocupação com o ambiente, e maior utilização dos recursos naturais pelo turismo, mas será que tudo que se diz ecoturismo, o é? O nome ecoturismo é novo, tendo surgido por volta dos anos 80 quando criada a Comissão Técnica Nacional constituída pelo Ibama e a Embratur, afim de disciplinar as atividades nesse campo. $\mathrm{O}$ ecoturismo é norteado por conceitos, de órgãos governamentais, e autores especializados em ecoturismo. Sendo uma atividade recente, pode haver falta de consenso sobre o que é ecoturismo, mas todos direcionam para uma prática sustentável. Unindo alguns dos conceitos, tem-se que o ecoturismo é um segmento do turismo que busca integrar visitante com a natureza (em especial com o ambiente visitado), preservando a identidade local e cultural, proporcionando o mínimo impacto e promovendo o desenvolvimento econômico com participação da comunidade. Alguns autores discordam, mas analisando o que é dito do ecoturismo por órgãos que estabelecem parâmetros, definições e princípios dos segmentos turísticos, e autores de alguns livros de referência na academia, a prática insustentável deste segmento não existe, pois tornarse-ia um outro segmento turístico, mas para que aconteça realmente o bom desenvolvimento do ecoturismo é necessário planejamento e manejo. Devido aos diversos problemas ambientais, o termo sustentabilidade vem sendo extremamente usado pelas empresas, turísticas ou não. Muitas empresas e cidades utilizam-se do marketing verde para atrair turistas, usando a denominação de destinos ecoturísticos, ou levando turistas a acreditarem que estão praticando ecoturismo, só porque estão em espaços naturais. Muitos dos destinos que ditos ecoturísticos, estão unidades de conservação, mas o que se nota é que, em sua maioria, não existe um planejamento para minimizar impactos causados pelo uso da área com o turismo, incluindo o estudo de capacidade de carga (e não se respeitando os limites, a prática de ecoturismo poderá tornar-se inviável, pois poderá causar impactos negativos). Seria importante que todo espaço dito ecoturístico, ou os que possuem potencial para este segmento do turismo, tivesse um planejamento ecoturístico, principalmente os em áreas de conservação. Analisando in loco a prática do ecoturismo no parque estadual da Pedra da Boca, em Araruna, Paraíba, percebe-se que já é considerado um dos principais pontos ecoturísticos da Paraíba, apesar de não possuir planejamento ecoturístico. Apesar disso, as visitas não parecem, visualmente, afetar o espaço. Com potencial e grande beleza cênica, já sendo "palco" de diversas práticas turísticas envolvendo trilhas, campings etc, torna-se ainda mais necessário o planejamento ecoturístico, principalmente por trata-se de uma área de proteção ambiental, podendo agregar o conhecimento de alguns moradores, como o morador e apaixonado pelo parque, apoiador da boa prática do ecoturismo, o guia "seu Tico", um representante no auxilio da educação ambiental, assim fazendo acontecer o verdadeiro ecoturismo. Apesar de ser uma Unidade de Conservação Estadual, o estado não realiza nenhuma atividade lá, nem apóia o ecoturismo que vem sendo realizado.

Palavras-chave: Ecoturismo; Planejamento: Pedra da Boca. 